\title{
DIMENSIONS OF THE CURRENT SYSTEMIC CRISIS: CAPITALISM IN SHORT-CIRCUIT?
}

\begin{abstract}
The crisis of global financial-led growth reflects evidence of exhaustion of the current model of accumulation, which has been in place since the late 70s, characterized by lower growth rates and decreasing labour shares. A system which so far has only been possible by means of excessive consumerism through increasing indebtedness, accelerated depletion of resources, growing income inequalities and social exclusion and unrest. Yet this is no longer sustainable. Since the end of the last century we can find and connect root signs of a multidimensional systemic crisis, which manifests itself today beyond the economic downturn in terms of buman, ecological and socio-political crises. In particular, increasing inequalities are analysed as a major factor bebind the evolution of the current economic crisis, but also behind that of other systemic imbalances. The contradictions that arise from the process of capital accumulation is the point of departure to look at this multidimensional crisis, which unfolds the expansive nature of capitalism and exposes the costs of the crisis beyond the economic one.
\end{abstract}

JEL classification: F01, F50, P16, P50

Keywords: Crisis, capitalism, inequality, human development, sustainability 


\section{Introduction}

We live today in a situation without precedent in the history of humanity. Never before has there been so many of us (the Earth now exceeds 7 billion inhabitants) and never before have we produced and consumed so much (world average GDP per capita having steadily increased until 2008). Moreover, we enjoy the most advanced technology and are more interconnected than ever before. But we are also currently experiencing one of the major crises of modern times. The current economic and financial crisis has reduced production and trade, destroyed millions of jobs worldwide, increased disparities both internal as well as international, exacerbated conflicts and violence, and intensified the exploitation of natural resources. But the current crisis goes beyond economic downturn. In this paper we argue that we are experiencing is a systemic crisis of multiple dimensions, namely an economic, human, ecological and socio-political one, reflected in global challenges of unprecedented intensity, magnitude and scope, and rooted in the very dynamics of the capitalist economic system, which has now clearly become unsustainable.

We analyse several global "crises" from a broad, integral and systemic perspective. Our goal is to show to what extent these crises are interconnected and can be considered as different dimensions of a systemic crisis. We first analyse the main dynamics behind the process of capital accumulation and economic growth in order to reveal how the inner contradictions - social and natural - that drive the process of surplus generation lead to recurrent crisis in capitalist economies. We then look a several indicators to track the parallel evolution of the different disruptions considered and to analyse potential interconnections between them. We analyse different dimensions of the systemic crisis by working with political, ecological and socioeconomic indicators from a general perspective, rather than independently as has usually been the case before. The aim of this paper is to advance the search for theoretical and empirical connections to the point of departure of all these overlapping crises. Our analysis suggests how recent dynamics indeed reflect deeper interconnected systemic disruptions, reinforcing each other and representing dimensions of a major systemic crisis of capitalism as the driving force of current socioeconomic, environmental and socio-political dysfunctions. Increasing inequalities seem not just play 
a major role in the evolution of the current economic crisis, but are also behind the evolution of the other systemic dysfunctions and their interconnectivity. Finally we discuss the manifested impossibility of capitalism to cover human needs worldwide, not only in terms of material wellbeing but also in terms of subjective satisfaction.

This paper is organized as follows: section 2 theoretically frames the existence of a systemic crisis of a multidimensional nature, associated with the exhaustion of the current model of accumulation and based on the two main contradictions capitalist development. Section 3 focuses on describing the different dimensions of this systemic crisis, tracing back key indicators for each dimension. Section 4 analyses interconnections between those dimensions and common root systemic causes. Section 5 concludes the paper and discusses policy implications of our analysis.

\section{Systemic crisis beyond economic crisis}

If most social scientists were asked about the political and socioeconomic problems that feature in our societies today the answer would probably be, at least intuitively, that it seems plausible to consider that those pertaining to system defaults are interconnected. The problem that arises is that the dominant economic paradigm, with Economics ruling over other social disciplines (Fine 2002), focused on extreme mathematical formalisation and characterized by an ahistorical perspective and an individualistic methodology, makes it difficult to explore the causes and impacts of the present multidimensional crisis. Not considering Economics as a monolithic body can be helpful in this sense (Sardoni 2009).

Consequently, it may be worth overcoming the well-known conceptual constraints of the dominant paradigm in order to reclaim a historical, social and interdisciplinary approach that the complexity of the phenomena currently emerging in our societies requires. Thus, the political economy approach, which defines Economics as the science that studies the laws governing the production and distribution of material goods and services to satisfy human needs (Lange 1966), can help us to overcome the narrow framework of orthodox (neo-classical) economics in order to explore in more depth some plausible explanation for what is happening today. We advocate for the need to advance conceptually towards a 
broader comprehension of the social realm by regaining the ability to connect different dimensions of the real world. ${ }^{1}$ That implies conceiving of our economic capitalist system as a mechanism that while fulfilling what should be its main objective (the reproduction of society in the material domain), also develops its own dynamics in terms of specific production and distribution relationships (Gill 2002). While capitalism is associated with progress, competition and efficiency as engines of growth, it is also linked to phenomena such as over-production, cycles, crises of profitability, exploitation of labour, overexploitation of natural resources and mercantilisation of life, in both personal and collective confines - such as childcare, leisure or the environment, among others. ${ }^{2}$ This "invasive" character of capitalism over social life has been well described by Harvey (2010), who points out that there are "seven activity spheres" which capital needs to conquer in order to accumulate. ${ }^{3}$

At the present stage of capitalism's global phase, it is fundamental to explore how the system develops in the globalized economy, the dynamics of which are featured mainly by cyclical crisis and unequal development (Caputo et al. 2001). In this sense, the present crisis clearly shows that beyond its economic manifestation in terms of product downfall, investment and employment, we can talk about a structural crisis in the sense that it confirms the breakdown of the accumulation process dating from the seventies, sustained by neoliberal finance-led growth and which has exhausted its capacity to foster growth and profitability. Again, capitalism has had to face up to problems of over-accumulation and over-capacity, which are intrinsic to its reproduction dynamics. ${ }^{4}$ What Marx showed was not only the contradictions of capitalism over time, but also that these contradictions arise from its own inner logic (Harvey 2010; 2014). Thus, capitalist development breeds recurrent crises, in the sense that capitalism's instability is systemic (Wolf 2010). After the global crisis of the 1870s and of the 1930s, the current crisis represents a crisis "of" the

\footnotetext{
1 As Amin's (1974) call for the need to "prepare the ground for universal social science".

2 Picchio's (2001) analysis of the missing attention in economics to consider and value social reproduction work, in its role of sustaining the whole (production) system, allows us to understand the growing invisibility and disregard of quantitative and qualitative value of reproductive work in terms of welfare and "standard of living", in line with Sen (1987). By considering pollution as a commodity that can be bought and sold, the European emissions market is another example reflecting the concept of marketisation.

3 These spheres are: technologies and organisational forms, social relations, institutional and administrative arrangements, production and labour processes, relations to nature, the reproduction of daily life and of the species, and "mental conceptions of the world".

${ }^{4}$ Because in fact, despite of decreasing rates of return and growth, the capitalist system has been able to increase investment rate in fixed assets due to (Caputo): i) new technology base (easing lower technology costs); ii) crowding
} 
capitalist mode of accumulation rather than a crisis "in" the capitalist system, as pointed out by different authors (Krugman 2008; Martins 2010; Florida 2010; Jessop 2012). While 1929 was the explosion of a structural crisis of the earlier liberal form of capitalism, 2007 represents the explosion of a crisis of the accumulation model of the modern neoliberal form of capitalism that dates back to the late 70 s/early 80 s (Kotz 2009).

When analysing the present depression as the expression of the end of the accumulation model of the last forty years, it could therefore be considered as an economic downfall in Marxist terms; that is, that capitalism can only solve its crisis by a crisis. As Brenner (2012) points out, "to actually resolve the problem of profitability that has so long plagued the system - slowing capital accumulation and calling forth ever greater levels of borrowing to sustain stability - the system requires the crisis that has, for so long, been postponed".

Moreover, capitalist development, linked to recurrent investment to foster progress and hence increasing profitability rates, has progressively colonized other dimensions of social life overreaching its own limits beyond the economic realm. The most visible reversals are exemplified by ecological unsustainability, human deprivation, socio-political unrest or even personal disaffection in spite of increasing income. When defining a systemic crisis we refer to one that affects the whole social system, ${ }^{5}$ rooted in the capitalist relations of production, distribution and consumption that show their own limits. ${ }^{6}$ In broader terms, we can talk about a systemic crisis beyond the economic crisis and related not only to the aforementioned structural crisis in the capitalist system as an accumulation regime, but also to the phenomenon associated with the surpassing of the limits of sustainable self-regulation, and selfactualisation of basic human needs. In fact, as we will see later, the manifestations of such a systemic crisis, as is the current one, are multidimensional, and its global and universal character has never been so clear. In this line, recent analyses from a socioeconomic or political perspective have begun to analyse the

out large mass of workers (worsening the capacity to create employment); iii) increasing competition (due to globalization).

5 In Mèszáros's words (2006) a crisis that affects "the totality of a social complex".

${ }^{6}$ Wallernstein (2001) refers to some of these disruptions of the capitalism system as "structural asymptotes". 
existence of overlapping crises today (Tabb 2008; Harcourt 2009; Addison et al. 2010; Gallagher and Ghosh 2010; Jessop 2012).7

We focus on the two contradictions that the capitalist mode of production has historically faced, in order to explain different dimensions of the current systemic crisis. Taking as a point of departure the Marxian category of the double character of production of use-value and exchange-value, we find this double contradiction engrained in the social as well as in the natural conditions of the accumulation process. As capitalist development unfolds, it generates both contradictions born from capital-labour relations on the one hand, and from society-nature relations on the other. These contradictions are manifested globally today in the inability of the system to satisfy human needs as well as in its tendency towards ecological breakdown.

The first contradiction refers to the logic of exchange-value, linked to accumulation processes, which dominates use-value as the production of those products that society needs for its own reproduction. Hence, worldwide we observe features of dualism, disarticulation and poverty, as direct expressions of the limits of capitalism to globally satisfy human needs and economic welfare. Thus, different approaches to unequal development may better link systemic dynamics to underdevelopment, which manifests the structural constraints of this model of accumulation to foster equal economic opportunities. ${ }^{8}$

The second contradiction is reflected in ecological degradation. By continuously increasing needs, the system requires constant economic growth; otherwise it collapses (Jackson 2009). But while sustainable growth might be impossible, world economic growth is impossible without further environmental degradation (Daly and Townsend 1992). This contradiction is directly related to the double character of the accumulation process, and specifically to the social mechanisms of alienation of workers from the conditions of production (Foster 2000; Burkett 2006). Capitalist development has distorted the bonds

\footnotetext{
${ }^{7}$ Even recently, the IMF acknowledges the existence of a triple crisis; economic, environmental and social (article in Centre for Global Development web page, june 12, 2012).

8 Theories developed by authors like Amin,Gunder Frank, Wallernstein, Dos Santos andSunkel, among others. Some authors(Pieterse 1996; Gore 2000)have highlighted the need to re-conceptualize some aspects of development theories linked to globalization character of current capitalism and to advance towards an alternative paradigm.
} 
between men (and women) and nature, which reflects Marx's core notion of commodity fetishism in the sense that it is the production process which dominates men, and not the other way round (Sweezy 1942). Ecological degradation is thus associated with the race for progress -and endless growth, intrinsic to capitalism and exemplified by impacts in the wake of the production process but also in the depletion of resources. It is in this ecological dimension where capitalization processes embracing extra-economic realms become most apparent. The environmental domain has been trapped under the logic of capitalism through the commodification and privatization of nature without considering its specificity as a means of livelihood. ${ }^{9}$ Harvey (2014) considers Seventeen Contradictions of capitalism, where endless growth driven by compound rates arises as one of the most-"dangerous".

Both contradictions are well reflected in the impact that capitalist development has on "non-material" dimensions of human life, that is, those areas that are beyond economic welfare achievement - understood as the availability of goods and services. Consequently, there is a progressive loss of those "spaces" which are considered vital for individuals - domestic, communitarian and environmental - pushed by the need to deliver them via the market. ${ }^{10}$ The question that arises here is to what extent this trend of marketisation of the vital domains for human beings has diminished their effective well being in terms of personal satisfaction. ${ }^{11}$ An apparent paradox appears in the sense that "growth can be social decline by another name" (Cobb et al. 1995), because satisfaction of some non-material needs, once basic means are satisfied, are mostly not related to the production sphere (other non-material needs, as knowledge, are of course essential for production). Furthermore, as Burkett (2005) exemplifies with free time, the satisfaction of "secondary needs", which are less energy intensive, can reduce the impact on natural conditions.

As mentioned before, if a systemic crisis is considered as one that affects the whole social system, in turn rooted in both - social and natural - capitalist contradictions, it is possible to identify the existence of overlapping crises as "dimensions" of one systemic crisis. Our aim is to transfer these "contradictions"

\footnotetext{
${ }^{9}$ See for instance Howard (2012).

${ }^{10}$ However, this marketisation of personal services, which is an intrinsic feature of capitalism, can diminish as a result of the restrictions imposed by the present crisis; a sort of re-switching in which services previously provided by the public sector are now produced within the household as the only way to cope with the crisis.

${ }^{11}$ As Sen (1987) points out "while Marx's attack on 'commodity fetishism' was made in a rather different context, that attack is deeply relevant to the concept of standard of living as well".
} 
(analytical approach) into "dimensions" (empirical approach) in order to make our analysis operative, through the review of recent data.

\section{Identifying Dimensions of the Systemic Crisis}

The main challenges we face today cannot be analysed, nor treated, separately. They are, as we expect to show, dimensions of a single systemic crisis associated with the exhaustion of the current global model of accumulation. The present economic and financial crisis that started in 2008 has had major global reach, affecting low, medium and high-income countries, and more people than possibly any crisis before. But, as explained previously, the current economic and financial crisis is at the same time a crisis that is endogenous and structural to the current capitalist system itself, and just one dimension of a wider systemic crisis. A crisis revealing, as will be shown, that our model of economic development not only doesn't deliver material wellbeing and higher satisfaction (for both underdeveloped countries, just as no longer for many of the most industrialized ones), but also that this model has become critically unsustainable.

We focus on a series of recent interconnected dynamics that allow for at least four different dimensions of the present systemic crisis: an economic and financial crisis, a human crisis of underdevelopment, an ecological crisis, and a socio-political and institutional crisis. In order to show these interconnected dynamics, we focus on selected indicators that we believe reflect the multidimensional nature of the crisis while keeping the analysis as simple a possible (not to say that other indicators could also be relevant). We prefer indicators at world level but also rely on indicators at national level (when more suitable or when global data is not available) to reflect these dynamics, which we consider of global reach.

\subsection{Economic and Financial Crisis}

Several authors have analysed the crisis as a systemic crisis of capitalism. Although there are some conflicting points among them from a theoretical point of view, all of them converge in the conceptualization of the exhaustion of the accumulation model, operational for the last forty years of global capitalist growth (Brenner 1998; Caputo 2001; Arrighi 2005; Foster and Magdoff 2009; Duménil 
and Lévy 2011; Chandrasekhar 2012; Mazzucato and Perez 2014; Pikkety 2014). We can therefore point to three basic features that have characterized this pattern of recent expansion: i) declining rate of growth in the world economy (mainly OECD countries, but also many developing ones) since the 1970s, with recurrent crises reflecting the cyclical nature of capitalist development; ${ }^{12}$ ii) increasing distributive conflict (between and within countries), which generates insufficient demand to absorb over-production and the subsequent need for public and domestic indebtedness; iii) Neo-liberalism as the predominant "strategy" intended to recover capital profitability through financial expansion, sustained by an artificial and unstable base and supported by governmental policies. ${ }^{13}$ Deep within these basic features of global financial-led growth, and in the exhaustion of the present model of accumulation, the root cause of the current economic and financial crisis can be found.

According to Pikkety (2014), decreasing rates of economic growth, lower than the return to capital, have lead to the capital-income ratio to increase since the 1970 s - as it happened during the eighteen and nineteen centuries until WWI - which eventually becomes economically and socially destabilizing. Moreover, "the very high level of private wealth that has been attained since the 1980s and 1990s in the wealthy countries of Europe and in Japan, measured in years of national income, directly reflects the Marxian logic" (Piketty 2014).

Some common features between the Great Depression and the Great Recession can be mentioned from the point of view of causal factors. First of all both crises are directly related to the "financial instability hypothesis" in Minsky (1992) terms, which would include uncertainty, bubbles and lending boom just before the downturn. ${ }^{14}$ Secondly, as noted by Pikkety, increasing inequality, feeding growing indebtedness and as major driver behind both crises, can be visible in both pre-crisis periods. In fact, a joint evolution on income inequality on the one hand, and of household debt to income ratios on the other, has already been highlighted (Kumhof and Ranciere 2010). Finally, also common to both crises is the paradoxical

\footnotetext{
${ }^{12}$ Following the post-war period a low rate or return implies that not only that the world economy experienced more cyclical dynamics but they have also been more pronounced.

${ }^{13}$ Harvey (2010) refered to this alliance as the "State-finance nexus".

${ }^{14}$ Some authors note that it is not just the increasing role of finance which matters but also the type of finance. Short-term speculation is ultimately the consequence of the lack of innovation and technological revolutions and therefore to the lack of long-term investment opportunities (see for instance Perez 2009).
} 
unconditional trust in market robustness and efficient markets by monetary authorities just before the turmoil starts. Some differential factors between both crises can also be highlighted. Probably the main difference lies in the context in which each crisis has developed. Particular of the current downturn are the neoliberal policies guiding financial deregulation (Bresser-Pereira 2010) and a globalized context evident since the mid-70s, which impinge a greater interdependence among economies as well as its spreading effects in case of any external shock - as the case of rapid transmission of financial crisis in Asian economies to the rest of emerging countries in the late 90s. Regarding consequences linked to a financial crack in both cases, similarities can also be observed in almost any developed country. Among these we can highlight a deflationary pressure in asset prices, massive unemployment, decreasing international trade and widespread bankruptcies and defaults, all accompanied by restricted credit liquidity and the associated negative impact on productive activity.

Returning to the current recession, excessive borrowing is what was first seen as the source of the financial crisis (Taylor 2009); easy credit and cheap money fuelled asset and financial bubbles which became unsustainable and imploded in 2008, dragging the financial and, later, the real estate sector into a crisis of global magnitude given the high level of worldwide financial interdependence. ${ }^{15}$ But excessive borrowing has been seen as a consequence of a global excess of capacity and resources for investment that, in the hunt for higher profits, were channelled towards the private sector in the form of credits for consumption and housing in the developed economies under a framework of high financialisation and imbalances (Tridico 2012); a "saving glut" that has been pinpointed by many authors as the origin of the crisis (Skidelsky 2009; Posner 2009; Obstfeld and Rogoff 2009; Lim Mah-Hui and Hoe Ee 2011). ${ }^{16}$ Moreover, financial deregulation and the recurrent search for higher short-term profits explain also the indebtedness boom. In this case, speculative investments are clearly delinked from real production not adding productive surplus to the economy but only generating high financial benefits (Tabb 2008;

\footnotetext{
${ }^{15}$ Love and Mattern (2011) review the causes, consequences and responses of the Great Recession.

${ }^{16}$ As Lim Mah-Hui and Hoe Ee (2011) explain, the global savings imbalances are associated to global imbalances in current accounts, with countries like China compensating its excess capacity by a large trade surplus and recycling the savings toward developed economies, and developed countries like the US compensating by over-consumption resulting in asset bubbles.
} 
Martínez-Peinado 2010). ${ }^{17}$ Finally, the search for increased productivity and profits has been associated with a lower participation of wages and salaries in national income (as in Pikkety's argument) and lower relative need for labour, implying lower employment and stagnated salaries. ${ }^{18}$ Increasing supply combined with stagnated salaries for middle-income groups has resulted in a lack of effective demand (actual demand determined by purchasing capacity), which helps us to understand the excess of resources for investment and the need to increase borrowing to compensate for that lack of demand. ${ }^{19}$ Guided by this last approach, increasing inequalities, which weaken demand relative to supply, have recently been seen as the main origin of the crisis (Barba and Pivetti 2009; Stiglitz 2009; Brescia 2010; Rajan 2010; Saith 2011; Peet 2011, Martins 2011; Tridico 2012) and the systemic nature of the crisis is acknowledged (Kotz 2009).

Thus, as a manifestation of a model of accumulation that gets exhausted, we can analyse the current economic and financial crisis by tracing back the signs of such a decreasing trend. As Figure 1.A shows, since the 1970s, GDP per capita tends to reflect lower average growth rates and higher volatility. In spite of economic booms in some periods, our current system has clearly been losing pace and is becoming more unstable and cyclical in the last 40 years. In fact, this feature is related to the economy's continuous need to increase capital investment (linked to fierce competition and full globalization), which has caused decreasing capacity utilization rates in manufacturing in developed countries (as in the case of USA). Notwithstanding, we can observe a clearly different path of economic performance between developed and developing countries (Figure 1.B). As expected, the higher dynamism of emerging countries - mainly China - and their increasing productivity pace of development contrasts with declining productivity in OECD countries - mainly the US. These differentiated productivity performances between developing and developed countries are clearly visible in the great external imbalances of leading countries. ${ }^{20}$

\footnotetext{
17 As Bresser-Pereira (2010) point out, the financialisation process has created an artifical financial wealth gaining control over social surplus.

${ }^{18}$ Real wage rates for middle-income groups across much of the globe have stagnated or shrunk relative to top income earners in their respective countries (Vandermoortele 2009), what has been labed as "job polarization". ${ }^{19}$ In fact, the same Mah-Hui and Hoe Ee show that there is a clear relation between increasing inequalities within countries, financial instability and crisis; increasing inequalities have led to higher savings for the rich and lower purchasing power for the poor and, therefore, have also led to stagnated aggregate demand that explains the problem of excess capacity, over-accumulation and over-supply.

${ }^{20}$ The Varoufakis (2011) metaphor of the US economy as the Global Minotaur analyses this external imbalance as a mechanism of surplus recycling.
} 


\section{Productivity, decreasing wages and excessive indebtedness}

There is a problem of the distribution of productivity gains, manifested in an increasing gap between labour productivity and wages in manufacturing. ${ }^{21}$ Figure 2 shows two clear examples: the cases of the USA and Japan. In the case of the USA it is in the early 80 s when the divergence between salaries and productivity begins despite both still growing. In the case of the Japanese economy, while the divergence starts later, it is mostly associated with stagnant salaries. The liquidity trap that Japan has been experiencing for a long time could be a national example of a lack of effective demand, as is the case in the global economy today. In any case, both examples reflect the capacity of the system to improve capital efficiency but with the side effect of crowding people out in terms of contained salaries and reduced net employment generation (highly associated with technological change).

If output per employee in manufacturing is increasing more than employee earnings, then a shift of income from labour to capital occurs, which provokes a situation of insufficient demand - and thus asserts the contradiction between productivity and profitability. Therefore, given insufficient demand, the economic growth of the last few decades has been sustained by growing indebtedness - both private and public - as an anti-cyclical mechanism. Although increasing public debt has been a common post-war phenomenon since that period, it is since the 1980s that the process of growing indebtedness has become more acute, as Figure 3 shows. At the same time, the decreasing shares of wages over GDP are also visible in the falling household rates of savings in developed countries (Figure 4).22 Additionally, stagnated purchasing power in these countries is very likely to bring social tension. But just as overproduction has been met by overconsumption, social tension has been tamed by the possibility of higher living standards - above the individual's income capacities, both through easy access to credit, temporarily feasible, but unsustainable in the long run.

Decreasing GDP growth rates for the world economy are mostly driven by developed economies, which still account for two-thirds of global GDP. But emerging economies with major shares on product and

\footnotetext{
${ }^{21}$ Folllowing ILO definitions and statistics.
} 
trade have also implied a structural change in the global system. ${ }^{23}$ In fact, fast growing developing countries (the so called BRICSs) have fostered their growth rates based on increasing involvement in the global economy; mainly through increasing merchandise exports and foreign investment flows (OECD, 2010; IMF 2012b; World Bank 2011; UNCTAD 2011). However, emerging economies have not yet reinforced a similar path of growth for domestic consumption; most of these emerging economies are developing more as global producers rather than consumers. ${ }^{24}$ Moreover, for the developing world the disrupted capitalist development that features in these societies is demonstrated by the spreading of dualism in most of them; 25 it can also be seen in the still meager rate of salaried workers. ${ }^{26}$ Thus, whatever the case, dualism in developing countries, just as with decreasing labour rents in developed countries, has led to a structural problem of increasing inequalities in the world economy.

\section{Increasing inequalities:}

Indeed, as previously suggested, increasing inequalities might be a major driver of the current economic and financial crisis. Increasing inequalities may be associated with growth at early stages of development as long as income distribution does not deteriorate too much, as they allow for concentration of resources necessary for economic development (Castells-Quintana and Royuela 2014). But increasing inequalities can also perpetuate themselves as a consequence of the very dynamics of the current economic system; they are rooted in the accumulation process characteristic of the capitalist system itself. In fact, during the last two centuries income distribution between nations and between populations within those nations deteriorated conclusively until 1980 (Bourguignon and Morisson 2002). From 1980 to 2000 this trend was compensated basically by the significant catching-up of large and poor countries like China and India (thus

\footnotetext{
${ }^{22} \mathrm{It}$ is worth mentioning the case of the USA where the participation of wage and salaries in national income has decreased from 59.3\% in 1970 to 51.6\% in 2006, reaching this year its lowest level on record (Center on Budget and Policies Priorities, 2012)

${ }_{23}$ The BRICSs (Brazil, Russia, India, China and South Africa) share on global GDP has grown from 3.9\% in 1970 to $12.8 \%$ in 2010 . In the case of exports that share has grown from $2.7 \%$ to $13 \%$ (UNSTATS).

24 The increasing gap between emerging countries and developed countries in terms of their participation in global product vis-a-vis global consumption would be expressing the difficulties facing emerging countries to retain their surplus (Martínez-Peinado 2011; Cairó-i-Céspedes and Martínez-Peinado 2012).

${ }^{25}$ Informal employment (as \% of non-agricultural employment) reported recently by ILO for some developing countries remains high, even for the emerging ones (2009): India (83,6\%), Ecuador (60,9\%), Mexico (53,7\%), Egypt $(51,2 \%)$, Brazil (42,2\%), Thailand (42,3\%), China (32,6\%). (ILO 2012).

${ }^{26}$ The weight of wage and salaried workers (as percentage of total employees) in India (15\%, 2005), Indonesia (34\%, 2009), Thailand $(45 \%, 2009)$, and Morocco $(44 \%, 2009)$ is far from that of OECD countries like USA $(93 \%, 2008)$ (KILM, ILO database).
} 
reducing inequality between countries if population size is acknowledged). But the key issue is the greater importance of inequality within nations in recent decades, and this has happened as much in developed countries as in developing countries (Figure 5). In fact, as Figure 6 shows, combining inequality between nations and with other nations, it is estimated that global inequality continued to grow after 1980, being the estimated Gini coefficient close to 0.7 in 2008 (Milanovic 2012).27 As Rodgers (2011) highlights, inequality remains as the most important concern of our time, and should be an issue of urgent worry (Wade 2011). Furthermore, a critical characteristic of today's inequalities is the disproportionate share of income and wealth in the richest few. In the USA the income share, including capital gains, of the top 0.1 per cent reached the highest in 2007, even above 1929 levels (World Top Incomes Database). Similarly, it is estimated that the one richest per cent of the world owns 40 per cent of global assets (Davies 2008).

The increasing relevance of inequality within countries is taking us back to a Marxist world of class struggles in which capitalism becomes unstable. "Social inequality produces instability, recession and depression... inequality is not only unethical but also it is economically disastrous" (Peet 2011). In effect, current increasing inequalities represent a perpetuating factor of the crisis; on the one hand they can be associated with higher unemployment and lower long-run economic growth (Castells-Quintana and Royuela 2012), and on the other hand the fact that income and wealth tend to concentrate disproportionately in few hands implies severe accumulation of power and political constraints to change (Kumhof and Ranciere 2010). Finally, inequalities also represent a major transmission mechanism that links the economic crisis to the other dimensions of the systemic crisis in a self-reinforcing process. As the World Development Report 2005 puts it, the "adverse effects of unequal opportunities and political power on development are all the more damaging because economic, political, and social inequalities tend to reproduce themselves over time and across generations." In particular, as we will see, increasing inequalities are associated with, and also help us to understand, the human-development, environmental and socio-political dimensions of the systemic crisis.

\footnotetext{
${ }^{27}$ Milonovic (2010) explains three concepts of inequality: 1) between nations, 2) between nations weighting by population, and 3 ) between individuals regarding where they live (that is taking into account also inequality within
} 


\subsection{Human and development crisis}

Our economic system, and in particular its unequal distribution structures of wealth and income, an uncontrolled demographic explosion and the degradation of the environment associated to it, place us in front of human crisis of global reach. This is a crisis characterized mainly by a growing number of total people in extreme poverty in a planet where the majority still lives in a situation of underdevelopment. Billions of people lack access to basic human needs such as potable water, sanitation, housing and education, and in too many cases they face deterioration in their quality of life, rather than an improvement (despite great internal and international efforts and a general process of convergence in many aspects of human development during previous decades, according to Kenny 2005).

\section{Hunger}

The year 2015 was the target date for the Millennium Development Goals (MDG). The first major goal was to eradicate extreme poverty and hunger. Success has been limited and with large geographical differences (see MDG Monitor). In 2005 it was estimated that still 1.4 billion people lived on less than US $\$ 1.25$ a day, which is considered as the international extreme poverty income threshold and meaning persistent difficulties to satisfy minimum dietary requirements.

Figure 7 shows the evolution of total population, undernourished population and food production (all worldwide). As can be seen, food production up until the 1990s was associated with a significant decrease in total undernourished population around the globe. Since the 1990s, food production has soared exceeding total population growth - but the total number of those undernourished is no longer decreasing: an astonishing 925 million people were suffering from chronic hunger in 2010 (FAO estimates), about 100 million more than in 1990. In parallel, food prices have increased sharply since the early 2000s. ${ }^{28}$ In particular, they soared between 2007 and 2008, at the same time the economic crisis erupted, and have done so again since $2010 .{ }^{29}$ Rising food prices and the current global economic downturn drove an

nations). While inequality under concept 2 has declined since 1980, inequality under concept 1 and 3 grew between 1980 and 2000.

${ }^{28}$ Bio-fuels play a relevant role in the increased demand for some crops. Moreover, the dramatic increase in food prices between 2007 and 2008 has also launched a race for transnational land acquisition.

${ }^{29}$ The food prices boom cannot be delinked of finance speculation (Clapp and Helleiner 2012). 
estimated extra 64 million into extreme poverty and hunger just in 2010 alone (UN Summit 2010). It is estimated that about 10 million people die of hunger and hunger related diseases yearly (MDG Monitor).

Recent statistics and reports suggest that past improvements in several of the other MDG have also stopped or even reversed recently due to the economic crisis. According to Human Development Indicators trends, GNI per capita, at world average, decreased in 2008 for the first time since 1980. In parallel, expected years of schooling, again at world average, also stoped in 2008 a steady growth since 1980. Even more dramatically, life expectancy at birth also decreased in 2010 for the first time since 1980.

The increasing inequalities associated with our economic system, reinforced by higher food prices in the midst of the crisis, support our incapacity to decrease hunger worldwide in a sustained way, despite higher food production, as well as our incapacity to cover basic human needs for all.

\subsection{Ecological crisis}

In parallel to the economic and human crises we also face a critical global environmental crisis. It is by now well recognized that human activity is driving the Earth system outside its stable environmental state, with potentially catastrophic consequences. As with the other crisis, the ecological crisis is interconnected in reinforcing ways with the other systemic imbalances, and also intrinsic to capitalist development based on capital accumulation. The crisis is the result of more than a century of industrial development worldwide, that relies on carbon-based energy sources, and placing as in a new era, the Anthropocene, in which human activities have been the main driver of global environmental change (Rockström et al. 2009). It is driven by a continuously increasing economic system, based on limited resources and radically different than ecological systems characterized by cyclical functioning (Roca 2001). It is intrinsic to capitalism as it can be situated in a network of social, political and economic structures creating a deep rift in the metabolic relation between human beings and nature metabolism that is the basis of life itself (Foster 1999; Foster et al. 2010; Howard 2012). This rift includes a disruption of natural processes and cycles as well as the accumulation of waste and environmental degradation. Thus, according to Clark and 
York (2005), the systemic degradation of the biosphere reflects how capitalism consumes everything in order to survive, even the natural resources that sustain the system itself.

The ecological crisis is parallel and reinforcing in the other systemic imbalances as changes induced in nature feedback, influencing social conditions for humans. In fact, rapid accumulation of wealth has been possible thanks to massive and unequal appropriation and extraction of natural resources, setting the bases for global environmental wreckage and global inequalities (Simms 2009). As a consequence, we face a challenging trade-off between sustainability and economic growth; the system is characterized by unsustainable exponential economic growth (Martenson 2011) and by overproduction in the midst of unmet social needs - with the struggle of billions of people to also benefit from economic development adding pressure to the resource base of the planet (Tabb 2008).

Indeed, our ecological crisis has become especially critical today. We experience a "triple crisis" of finance, energy and the environment. However, paths to recovery have neglected or marginalized ecological issues (Jessop 2012) - as well as environmental concerns have until recently been generally outside most economic analysis. ${ }^{30}$ Worryingly enough, the long-run trend of global warming has dramatically accelerated in recent years, despite technological advancements and despite stagnated production due to the current economic crisis. On the one hand, structural conditions under the current economic system limit the ecological benefits of technological development; the Jevons' paradox predicting that greater efficiency in resource use often leads to increased consumption of resources. We were indeed substantially more efficient at producing sustainable wellbeing in 1969 than in $2005 .{ }^{31}$ On the other hand, transformations associated to the economic crisis have actually accelerated the process; carbon emissions in 2010 showed the biggest jump ever recorded. ${ }^{32}$ Firstly, the main drivers of world economic growth are now countries like China which are much less energy efficient than developed countries and rely more heavily on fossil fuels (and as noted above, any increase in their energy efficiency will most likely translate

\footnotetext{
${ }^{30}$ Douai et al. (2012) briefly frame the prevailing literature on economics of the environment and sustainability, the recent theoretical developments from different schools and the current lines of research, especially from a heterodox perspective (see Special Issue of Cambridge Journal of Economics 2012, 36).

31 According to the Happy Planet Index, while happy life years have increased by 15 per cent over 45 years, per capita, ecological footprints have increased by 72 per cent.

32 Global Carbon Project.
} 
into more intensive use of fossil fuels, dramatically increasing total CO2 emissions). Secondly, and at least in the short run, the economic crisis may be restricting some unintended mechanisms through which we were counteracting global warming. ${ }^{33}$ Finally, the economic crisis and its social consequences, have driven away the increasing concern and political will that was mounting in favour of environmental conservation (Lovelock 2006).34

Rockström et al. (2009) identify up to nine planetary boundaries that define the safe operating space for humanity. ${ }^{35}$ As the different dimensions of the systemic crisis analysed in this work, the different planetary boundaries are not independent but interact with each other. In particular, there are currently three planetary boundaries which have already been transgressed and represent the main global ecological challenges of anthropogenic origin requiring special attention: 1) accelerated global warming (as mentioned before and highly associated with the acidification of the oceans, the rise of coastal levels, and alterations in the Earth's magnetic field), 2) the dramatic pace of biodiversity and natural ecosystems loss, and 3) the interference with the Earth's nitrogen and phosphorus cycles. ${ }^{36}$

\section{Ecological footprint}

One simple and synthetized way to evaluate our environmental impact, and our situation of ecological crisis, is by looking at our ecological footprint. Figure 8 shows how in recent decades our ecological footprint has constantly been exceeding our planet's capacity for recovery; an increasing "ecological debt" that we are accumulating with the planet. And ecological debt which also has at least 3 different

\footnotetext{
${ }^{33}$ Lovelock (2006),considering our planet and the life in it as a single self-regulating organism. had already warned us of such a possibility even before the current crisis erupted. One such unintended mechanism is the emission of short-term cooling-aerosols as a by-product of industrial production.

${ }^{34}$ Lovelock warns about the risk of higher carbon dioxide emissions if no strong support is given to realistic alternatives to fossil fuels, alternatives today mainly represented by nuclear energy. Not only the economic crisis but also events like the Fukushima catastrophe in 2011, strengthening the anti-nuclear movement, are leading to lower investments in renewable energy sources as in lower nuclear energy production.

35 The nine boundaries are climate change, rate of biodiversity loss, interference with the nitrogen and phosphourus cycles, stratospheric ozone depletion, ocean acidification, global freshwater use, change in land use, chemical pollution, and atmospheric aerosol loading.

${ }^{36}$ In terms of global warming, the Earth's average surface temperature has increased $0.8^{\circ} \mathrm{C}\left(1.4^{\circ} \mathrm{F}\right)$ since the early 20 th century, with about two thirds of the increase occurring since 1980, and with an estimated further increase of between 1.1 to $2.9^{\circ} \mathrm{C}\left(2\right.$ to $\left.5.2^{\circ} \mathrm{F}\right)$ and 2.4 to $6.4^{\circ} \mathrm{C}\left(4.3\right.$ to $\left.11.5^{\circ} \mathrm{F}\right)$ during the $21^{\text {st }}$ century, which severely threatens the natural system's capacity for adaptation. In terms of biodiversity, there was an estimated total decline of $28 \%$ in The Living Planet Index between 1970 and 2007 with no foreseeable sign of future recovery (Living Planet Report 2010).
} 
perspectives associated to global inequalities: 1) an inter-generational one, as most of current environmental burden is due to past unequal economic development, 2) an intra-generational one of still unequal use -and abuse- of natural resources, where those causing lower environmental deterioration are at the same time those who suffer the most from it, ${ }^{37}$ and 3) a trade-related one, as exports from the global south to the global north have a higher value in terms of natural capital not captured in the market price than exports from the north to the south.

In sum, our impact on the planet is greater and greater and in many aspects both difficult to reverse and highly worrying; there are more of us and we consume more. As we face economic and financial collapse (see section 3.1), as well as human deprivation (see section 3.2), we also face "environmental bankruptcy" - using Simms's (2008) expression.

\subsection{Socio-Political crisis}

All the imbalances reviewed (increasing inequality, hunger, poverty and environmental degradation) can be related to a crisis of governability, at national and international level, where institutions surely play a dramatic role. However, we focus here on the evolution of socio-political conflict and political disaffection within countries. In that line, the abovementioned imbalances have accentuated not only the human crisis but have also fuelled a growing number of conflicts producing more and more violent deaths and the abuse of fundamental human rights, that in turn feedback economic distortions. In fact, several authors have provided evidence on the links between inequality, social-political instability and economic growth (Alesina and Perotti 1996; Svensson 98; Keefer and Knack 2002). In Africa, violent revolutions, coups and wars follow on one from another, as the continent stagnates in poverty. The Middle East is still in endless conflict. Latin America, the most unequal region of the world, bleeds because of delinquency, drug trafficking and guerrillas. In Asia, governmental oppression and political polarization take the lives of millions. Worldwide we have a growing number of countries becoming failed states, without a functioning government or legal order (as is the case of Afghanistan, Iraq, Somalia, Sudan and South Sudan, among others). As Figure 9 shows, there has been an upward trend in armed conflict since the 1940s (cold war)

\footnotetext{
${ }^{37}$ See for instance Martinez-Alier (1997) and Sutcliffe (1997).
} 
but it is during the 1970s when the increase becomes dramatic (precisely as inequalities soar), only slowing down at the end of the nineties. In fact, a higher incidence of violent conflict is clearly demonstrated not only by the increasing number of refugees worldwide since the late 1970s, but also by the type of refugees: who are now characterized more by displacements due to intra-state conflicts than by international ones. ${ }^{38}$ The current neo-liberal globalisation represents a process of "detraditionalisation" (Gibbens 2003), where we feel in the grip of forces over which we have no control, question traditional ways of acting and lose self-identity, leading to political apathy, increased addictions and even the rise of fundamentalism.

Besides armed conflict, it is also worth mentioning an increase in urban riots and social disturbances. Although not classified as armed conflict, they can, in many cases, be considered as another worrying violent expression of growing social unrest; 39 a social unrest rooted in a deeper crisis of governability, both nationally and globally, against the exploitation by the governing elites, corrupt and insensitive to people's difficulties. ${ }^{40}$ Even in the so-called advanced democracies, as wealth dramatically concentrates in the hands of some few (as Milanovic and the World Top Incomes Database reflect) there is a clear distance between the people and their political representatives, as reflected in lower turnout indices (Figure 10). Both facts reflect the paradox of (liberal) democracy, that is, increasing social unrest and increasing disaffection of voters, occurring in a world where the percentage of countries who have democratic government has gone up from 31\% in 1960 to $58 \%$ in 2008 (HSRP, 2010).

\section{Systemic crisis and the impossibility of sustainable human development}

\subsection{Independent crises or interconnected dimensions?}

The different dimensions of our current systemic crisis, highly interconnected as we have seen, begin to show an unbalanced and harmful dynamic in the last quarter of the twentieth century. The supply driven economic growth of recent decades has led to a lack of effective demand as a result of the search for increasing profits and, therefore, a decrease in the working wage. Along increasing disparities in wages,

\footnotetext{
38 According to the Human Security Report Project, between 1998 and 2005 the number of refugees has increased globally. But while IDPs (internally displaced persons) have increased, displaced persons who cross a national border have decreased during this period (HSRP 2012)

${ }^{39}$ Urdal (2008) examines 55 major cities in Africa and Asia for the 1960-2008 period and accounts for 3,375 social disturbances, $40 \%$ involving fatalities, which according to the report are increasing in both continents.
} 
this has led to extreme and increasing inequalities - both inside countries and between them - and higher social exclusion (characterized by over-consumption by some and deprivation for many), which has also led to increased social tension and political conflict - in many cases violent. At the same time, overproduction and unequal access and exhaustion of our natural capital are leading to dramatic environmental degradation. Finally, as a consequence of all of these, we also face a crisis of values, beliefs and personal satisfaction (affecting both advanced economies and the developing world), which has become evident over the last decades. Figure 11 (Diagram 1) analytically synthesizes these interconnected imbalances, discussed throughout this paper as empirical dimensions of a single systemic crisis.

The existence of overlapping crises today is neither mere coincidence nor are these crises independent disruptions. Our theoretical and empirical analysis suggests that they are highly interconnected imbalances, reinforcing each other, rooted in the onset of modern capitalism, and becoming unsustainable in its current global-financial-led phase. The two aforementioned contradictions of capitalist development are primarily articulated today in terms of decreasing wellbeing, unequal global development and environmental collapse. If we consider the accumulation process in both its "social" and "natural" character, it would be the inner logic on capitalist development which gives us the interconnection between the dynamics of the economic/financial crisis and the increasing inequality, social exclusion, ecological depletion, conflict and social discontent.

The imbalances analysed represent the current economic, human, ecological and socio-political limits of capitalism and clear signs of the unsustainability of the system. Unsustainability in terms of the incapacity of the system to cover human needs of the whole population as well as in its inability to limit itself in terms of use (and abuse) of natural resources.

\subsection{Development beyond material wellbeing}

The existence of overlapping and interconnected crises - which as discussed above is related to the nature of capitalist mode to organize production processes - shows in the very end that a life based on increasing

\footnotetext{
${ }^{40}$ Examples can be found in the developing as well as in the developed world: from the wave of revolutions started
} 
consumption in an environment of social, cultural and natural degradation can easily be translated into major personal dissatisfaction. This "non-material" dissatisfaction could be the last expression of the systemic crisis in the sense that the race of capitalism to accumulate - well embedded in modern societies, which confuse "having" with "being"- is progressively invading most sacred spheres of social and personal life relating to nature, the community and even oneself.

In recent decades the development of alternative indicators reflect the shortcomings of GDP to express qualitative dimensions of wellbeing, and has highlighted the divergent trend between output performance and people's satisfaction. Some adjustments of GDP so it better reflects wellbeing include, among others, the correction for unequal distribution of income, the incorporation of non-market economy benefits associated (for instance) with housework, parenting or social tasks, and detracting costs associated with ecological degradation (see for instance Talberth et al. 2007 or Stiglitz et al. 2009). All of these adjustments try to emphasize the need to consider both objective and subjective dimensions of wellbeing. The decreasing capacity of GDP to enhance life satisfaction has already been shown by several authors focusing on "happiness economics" (from Easterlin 1974 to Stutzer and Frey 2010, among others). The first UN World Happiness Report (2012) studies determinants of happiness in societies around the globe. The Report highlights that is not just wealth what makes people happy. ${ }^{41}$

It is therefore interesting to analyse how material wellbeing translates into psychological experiences of fulfilment (Alkire, 2010). In Figure 12 we try to capture this dissociation between the measurement of socioeconomic wellbeing and people perception of it, by comparing (for 140 countries) per capita GDP with a subjective measure of wellbeing - Life Satisfaction Index (New Economics Foundation 2005). The figure illustrates two main points: first that higher per capita GDP correlates with higher life satisfaction but in a decreasing way. ${ }^{42}$ This pattern suggests that increasing incomes no necessarily contribute to improving wellbeing in all cases - in line with human development approaches. Second, that there is high variability in the levels of life satisfaction for countries with similar levels of per capita GDP, especially in

in the Arab world in 2010 to recent riots in major cities such as London, Paris and Madrid.

${ }^{41}$ UN World Happiness Report (2012). The Report highlights the great relevance of environmental issues in people's life satisfaction. 
poorer countries. This variability decreases as income increases, suggesting a process of satisfaction homogenization linked to income while devaluing other dimensions of personal well being.

Ultimately, it seems clear not only the inability of capitalist development to allow people to fully realize their capabilities, in the sense of Sen's human development approach, but also the incomprehensible byproduct of capitalism to recurrently displace human needs from the socioeconomic agenda. ${ }^{43}$ In any case, it seems plausible to agree that increasing growth and higher per capita income do not only mean that no better personal satisfaction occurs but, furthermore, that they might disguise things like social decay, the borrowing of future resources, or the shifting of functions from the traditional realm of household and community to the realm of the monetized economy. ${ }^{44}$

\section{Final considerations}

In this paper we have argued that the current crisis is a systemic one, rooted in the dynamics of capital accumulation. We have supported our argument on theoretical grounds as well as on the analysis of recent data for a broad range of indicators. As we have shown, the social and natural contradictions of the system manifest today in terms of unequal development, ecological degradation and social unrest. Nevertheless, the systemic character of the actual crisis refers not only to different converging crises but also to the global framework where these crises occur. Never before the connections between countries and classes around the world have reached the actual level of interdependence. While the current crisis can be considered as another crisis of capitalism in the sense that it has been fuelled by neoliberal globalization, it is noticeable that neoliberalism has just been a tool that capitalism uses to fulfil its process of capital accumulation.

Regarding the methodological approximation to the analysis of current global phenomena, and following an integral approach for the study of the systemic crisis, the still-existing constraints of economic analysis to fully understand a multidimensional crisis (and its inability to confront its consequent irreversible

\footnotetext{
42 Regression analysis suggests a non-linear relationship between both variables.

43 In Marx's words, by "replacing the domination of circumstances and chance over individuals by domination of individuals over chance and circumstances" (quoted from Sen 1983).
} 
impacts) has clearly emerged. In this line, two shortcomings can be highlighted. Firstly, a "perversity measurement", which relates to the recurrent economic trap, which gives value only to what can be measured while not taking into account the incommensurability of human well-being or the irretrievable loss of the natural environment. Secondly, a "conservative nationalism", which is reflected in the increasing dissonance between global challenges and national mindset, making it difficult to deal with a systemic crisis by the application of current tools, policies and wills engrained at national level. The crisis, as an expression of the shortcomings and contradictions of the current system, gives us the opportunity to face up to all these challenges as they represent a critical situation of fracture and discontinuity.

In terms of policy implication, our analysis shows that responses to the present recession are not taking into account its systemic and multidimensional character. Bailouts and other recovery receipts, as austerity measures, are aimed at overcoming the crisis by trying to restore previous growth rates, which only deepens capitalist dynamics that are precisely the root of the crisis. As it has recently highlighted, this strategy represents a return to a new form of neoliberalism as a contra-offensive strategy. ${ }^{45}$ In fact, recovery strategies based mainly on austerity measures lead to a vicious circle, which by reconstructing the capitalist base for accumulation it also increases workers' impoverishment and reduces social wellbeing. These strategies represent capitalism's own logic to solve recurrent crisis. If we indeed face a multidimensional systemic crisis, any recovery policy as well as any alternative of change, should take a broader and more integral perspective considering the economic as well as the human, environmental and socio-political dynamics and the interconnections between these dynamics. Hence, acknowledging the systemic and multidimensional character of the crisis, we emphasize the need for integral responses at both national and international level, with global coordination and cooperation required (but also with a local focus as most problems today are more clearly manifested at the local level).

From a structural perspective some economic interventions appear as fundamental: a correction of current global imbalances in savings and consumption and a strengthened regulation of global finances in order to re-link liquidity to productive investment. But addressing only the economic crisis, without paying

\footnotetext{
${ }^{44}$ As Cobb et al (1995) has pointed out in their critical approach to the GDP as a wellbeing indicator.
} 
attention to other global imbalances, will continue to prove unsuccessful in the long run. To begin with, any policy design should not exacerbate the inequalities and dramatic social consequences of the crisis. Reducing inequalities appears not just as a fundamental goal in itself and key instrument to address the current economic crisis, but also to address all the different imbalances inherent to the system and analysed in this paper, including the human, ecological and socio-political. Intra-generational redistribution is essential to simultaneously address poverty and environmental deterioration and therefore also represents inter-generational redistribution from this generation to future generations. Likewise, redistribution is also crucial to address social tension and political conflict. Indeed, the viability of any alternative successful strategy relies on a redistribution of wealth and the power associated with it.

More broadly, the design of alternative paths to the present situation should acknowledge the current inability of the capitalist economic system to ensure its main function of social reproduction. We have argued that the current systemic crisis is rooted in the inner dynamics of capital accumulation, which in turn have generated in a parallel way different reinforcing disruptions. Thus, the first question is therefore a technical one in the sense of how to face with the (contradictory) logic of accumulation that leads to a problem of surplus absorption. That is, not only how to appropriate and distribute the surplus workers produce in a collective and democratic way, but also how to socialize this surplus in a productive and profitable way. This leads us to reconsider the human question, that is, to wonder which kind of society we aim for, including a change in values and beliefs in order to build a sustainable human development. It also leads us to think about how to address the political engineering capable of articulating social change. In this way, further research and discussion are clearly needed.

\section{References}

Abdallah, S., Thompson, S., Michaelson, J., Marks, N. and Steuer, N. 2009. The (un)Happy Planet Index 2.0: Why good lives don't have to cost the Earth. New Economics Foundation, London.

Addison, T., Arndt, C. and Tarp, F. 2010. The triple crisis and the global aid architecture. UNU-WIDER, WP/01.

Alesina, A. and Perotti, R. 1996. Income distribution, political instability, and investment. European Economic Review 40: $1203-1228$.

${ }^{45}$ See for instance Brenner (2012). 
Alkire, S. 2010. Human Development: Definition, critiques and related concepts, Human Development Research Paper, 2010/01. UNDP.

Amin, S. 1974. Accumulation on a world scale: a critique of the theory of underdevelopment. Monthly Review Press, NY.

Arrighi, G. 2005. Hegemony Unravelling-2. New Left Review 33: 83-116.

Bourguignon, F., and Morrisson, C. 2002. Inequality among World Citizens: 1820-1992. The American Economic Review 92 (4): 727-744.

Brenner, R. 1998. The economics of global turbulence. New Left Review I/229, May-June.

Brenner R. et al. 2012. Neoliberalism resurgent? Market rule after the Great Recession, The South Atlantic Quarterly, $111(2)$.

Brescia, R. 2010. The Cost of Inequality: Social Distance, Predatory Conduct, and the Financial Crisis. NYU Annual Survey of American Law Vol. 66.

Bresser-Pereira, L. 2010.The global crisis and a new capitalism. Journal of Post Keynesian Economics 32 (4): 499-534.

Burkett, P. 2005. Marx’s Vision of Sustainable Human Development. Monthly Review 58 (4): 34-62.

Burkett, P. 2006. Marxism and Ecological Economics. Leiden, The Netherlands.

Cairó-i-Céspedes, G., and Martinez-Peinado, J. 2014.El desarrollo de una Semiperiferia como necesidad de la transición hacia el Sistema Capitalista Global: Una aproximación empírica a través del análisis factorial. Revista de Economía Mundial, 38 (3).

Castells-Quintana, D., and Royuela, V. 2012. Unemployment and long-run economic growth: The role of income inequality and urbanisation. Invetigaciones Regionales 24: 153-173.

Castells-Quintana, D., and Royuela, V. 2014. Agglomeration, Inequality and Economic Growth. Annals of Regional Science 52: 343-366.

Caputo, O., Estay, J., and Vidal, J. 2001.Capital sin fronteras. Polarización, crisis y Estado-nación en el capitalismo global. Icaria, Barcelona.

Centre on Budget and Policies Priorities. 2012. Share if national Income going to wages and salaries at record low in 2006. Washington DC.

Chandrasekahr, C. P. 2012. Critical perspectives on the Great Recession. Development and Change 43 (2): 603-613.

Clapp, J., and Helleiner, E. 2012. Troubled futures? The global food crisis and the politics of agricultural derivatives regulation. Review of International Political Economy 19 (2): 181-207.

Clarke, B. and York, R. 2005. Carbon metabolism, climate change, and the biospheric rift. Theory and Society 34: 391 428.

Cobb, C., Halstead, T. and Rowe, J. 1995. If the GDP is up, why is America Down? The Atlantic Monthly, October: 59-78.

Davies, J. B. (ed.) 2008.Personal Wealth from a Global Perspective .Oxford University Press, Oxford.

Douai, A., Mearman, A. and Negru, I. 2012. Prospects for a heterodox economics of the environment and sustainability. Cambridge Journal of Economics 36: 1019-1032.

Duménil, G., and Lévy, L. 2011. The crisis of neoliberalism. Harvard University Press.

Easterlin, R.A. 1974. Does Economic Growth Improve the Human Lot? Some Empirical Evidence. In Nations and Households in Economic Growth: Essays in Honour of Moses Abramowitz, ed. David P.A. and Reder M.W. NY.

FAO. 2012. FAO Statistics Division, http:/ / faostat.fao.org/

Fine, B. 2002. Economics imperialism and the new development economics as Kuhnian paradigm shift? World Development 30 (12): 2057-2070.

Florida, R. 2010.The Great Reseat. HarperCollins Pub, NY.

Foster, J.B. 1999. Marx’s theory of metabolic rift. American Journal of Sociology 105 (2): 366-405.

Foster, J.B. 2000. Marx's ecology. Materialism and nature. Monthly Review Press, NY.

Foster, J.B., Clark, B., and York, R. 2010. The Ecological Rift: Capitalism's War on the Earth. Monthly Review Press, NY. Foster, J.B., and Magdoff, F. 2009. The great financial crisis. Monthly Review Press, NY. 
Gallagher, K. and Ghosh, J. 2010. http://www.triplecrisis.com

Giddens, A. 2003. Runaway World: How globalisation is reshaping our lives. Taylor and Francis.

Gill, L. 2002. Fundamentos y limites del capitalismo. Trotta, Madrid.

Global Footprint Network. 2010. Living Planet Report 2010, WWF International, Gland.

Gore, C. 2000. The rise and fall of the Washington Consensus as a paradigm for developing countries. World Development 28 (5): 789-804.

Harcourt, W. 2009. Editorial: What Economics needs to become. Development 52 (3): 277-279.

Harvey, D. 2010. The enigma of capital, Oxford University Press.

Harvey, D. 2014. Seventeen contradictions and the end of capitalism, Oxford University Press.

Harvey D. "Estamos realmente ante el fin del neoliberalismo" in Estrada, J. Crisis capitalista, Espacio Crítico Ediciones. http://www.cronicon.net/paginas/Documentos/Crisis\%20capitalista.pdf

Helliwell, J., Layard, R. and Sachs, J. -Editors- (2012), World Happiness Report. The Earth Institute. http://www2.binghamton.edu/fbc/archive/iwleftpol2.htm

Howard, E. 2012. The ecological Rift: capitalism's war on the Earth. New Political Economy 34 (2): 252-254.

Human Security Report Project. 2010. Human Security Report 2009-10, http://www.hsrgroup.org/human-securityreports/20092010/overview.aspx

Human Security Report Project. 2012. The mini Atlas of Human Security.http://www.hsrgroup.org/ourwork/publications/miniatlas.aspx

International Labour Organization. 2012. Laborsta Database. http://laborsta.ilo.org/

International IDEA-International Institute for Democracy and Electoral Assistance. 2012. http://www.idea.int/vt/index.cfm

International Labour Organization. 2012. Women and men in the informal economy: a statistical picture. Country specific tables. http://www.ilo.org/global/topics/employment-promotion/informal-economy/lang--en/index.htm

International Labour Organization. 2012. Key Indicator of the Labour Market Database. http:// kilm.ilo.org/kilmnet

International Labour Organization. 2012. Laborsta. http://laborsta.ilo.org/default S.html

International Monetary Fund. 2012. Historical Public Debt Database, http://www.imf.org/external/pubs/cat/longres.cfm?sk=24332.0

International Monetary Fund.2012b. World Economic Outlook 2012.

International Monetary Fund. 2012c. The World Top Income Database. http://topincomes.parisschoolofeconomics.eu/

Jackson, T. 2009. Prosperity with out growth: Economics for a finite planet. Earthscan, London.

Jessop, B. 2012. Economic and Ecological Crisis: Green new deals and no-growth economies. Development 55 (1): 17 24.

Keefer, P., and Knack, S. 2002. Polarization, politics and property rights: Links between inequality and growth. Public Choice 111: 127-154.

Kenny, C. 2005. Why are we worried about income? Nearly everything that matters is converging. World Development 33 (1): 1-19.

Kotz, D. 2009. The Financial and Economic Crisis of 2008: A Systemic Crisis of Neoliberal Capitalism. Review of Radical Political Economics 41: 305.

Krugman, P. 2008. The return of Depression Economics and the Crisis of 2008.Penguin, London.

Kumhof, M., and Ranciere, R. .2010. Inequality, Leverage and Crises. IMF Working Paper 10/268.

Lange, O. 1966. Economía Política I. Problemas generales. Fondo de Cultura Económica, México.

Love, N., and Mattern, M. 2011. The great recession: causes, consequences and responses. New Political Economy 33(4): 401-411.

Lim Mah-Hui, M. and Hoe Ee, K. 2011. From Marx to Morgan Stanley: Inequality and Financial Crisis. Development and Change 42(1): 209-227. 
Lovelock, J. 2006.The Revenge of Gaia: Why the Earth is fighting back and how we can still save humanity. Penguin, London.

Martenson, C. 2011.The Crash Course. Wiley, NJ.

Martinez-Alier, J. 1997.Ecología y pobreza: Una crítica al Informe Brundtland. In Pobreza, desarrollo y medio ambiente, ed. Senillosa, I., 35-60. Octaedro. Barcelona.

Martínez-Peinado, J. 2010. La crisis actual. Una interpretación sistémica desde la óptica del proceso de circulación del capital. XII Jornadas de Economía Crítica, February, Zaragoza.

Martínez-Peinado, J. 2011. La estructura teórica Centro-Periferia y el análisis del sistema económico global. Obsoleta o necesaria? Revista de Economía Mundial 29: 27-57.

Martins, N. 2011. Globalization, inequality and the Economic Crisis. New Political Economy 16 (1): 1-18.

Mayer-Foulkes, D. 2009.Long-Term Fundamentals of the 2008 Economic Crisis. Global Economy Journal,9 (4): 1-25.

Mazzucato, M. and Perez, C. 2014. Innovation as growth policy: the challenge for Europe. SPRU Working Paper Series, SWPS 2014-13.

Mészáros, I. 2006.The structural crisis of politics. New Left Review 58(4): 34-53.

Milanovic, B. 2011. Global Income Inequality by the Numbers: in History and Now - An Overview. World Bank Policy Research Working Paper No. 6259.

Minsky, H. 1992. The financial instability hypothesis. Working paper No. 74. Levy Economics Institute.

Obstfeld, M. and Rogoff, K. 2009. Global Imbalances and the Financial Crisis: Products and Common Causes. CEPR Discussion Papers (7606).

OECD. 2010. Perspectives on Global Development: Shifting Wealth. OECD, Paris.

OECD. 2011. Economic Outlook, Volume 2011, Issue 2, n. 90.

Peet, R. 2011. Inequality, crisis and austerity in finance capitalism. Cambridge Journal of Regions, Economy and Society 4: 383-399.

Perez, C. 2009. The double bubble at the turn of the century: Technological roots and structural implications. Cambridge Journal of Economics 33(4):779-805.

Picchio, A. 2001. Sostenibilidad, equidad y crecimiento: una perspectiva feminista. In Capitalismo, Desigualdades y Degradación Ambiental, ed. Dubois, A. Millán, J.L., and Roca, L., 51-74. Icaria, Barcelona.

Pieterse, J. N. 1996. The development of development theory. Towards critical globalism. Review of International Political Economy 3 (4): 541-564.

Pikkety, T. 2014. Capital in the Twenty-First Century. Harvard University Press.

Posner, R. A. 2009. A failure of Capitalism.MA, Harvard University Press, Cambridge.

Rajan, R. 2010.Fault Lines: How bidden fractures still threaten the world economy, Princeton University Press.

Roca, J. 2001. El debate sobre el crecimiento económica desde la perspectiva de la sostenibilidad y la equidad, In Capitalismo, Desigualdades y Degradación Ambiental, ed. Dubois, A. Millán, J.L., and Roca, L., 17-50. Icaria, Barcelona.

Rockström, J. et al. 2009.A safe operating space for humanity. Nature 46 (24): 472-475.

Rodgers, D. 2011. Introduction: The Politics of Poverty and Inequality. European Journal of Development Research 23: 511-512.

Saith, A. 2011. Inequality, Imbalance, Instability: Reflections on a structural crisis. Development and Change 42 (1): 7086.

Sardoni, C. 2009. The present crisis: should we go beyond economics? Development 52: 308-12.

Sen, A. 1987. The standard of living. The Tanner lectures on human values, Cambridge University.

Sen, A. 1983. Development. Which way now? The Economic Journal 93 (372): 745-762.

Simms, A. 2009. Ecological Debt (second edition). Pluto Press, NY.

Skidelsky, R. 2009. Keynes: The return of the Master. Public Affairs, NY.

Stiglitz, J. 2009. The global crisis, social protection and jobs. International Labour Review 148 (1-2): 1-13. 
Stiglitz, J., Sen A. and Fitoussi, J. 2009. Report by the Commission on the measurement of economic performance and social progress.

Stutzer, A., and Frey, B. 2010.Recent advance in the Economics of Individual Subjective Well Being.Social Research 77 (2): 679-714.

Sutcliffe, B. 1997. Desarrollo, redistribución y medio ambiente. In Pobreza, desarrollo y medio ambiente, ed. Senillosa, I., 99-144. Octaedro. Barcelona.

Svensson, J. 1998. Investment, property rights and political instability: Theory and evidence. European Economic Review 42: 1317-1341.

Sweezy, P.M. 1942. The theory of capitalist development. Principles of marxian political economy. Oxford University Press, NY.

Tabb, W. 2008.Four Crises of the Contemporary World Capitalist System. Monthly Review 60 (5): 43-59.

Talbert J., Cobb, C. and Slattery, N. 2007. The Genuine Progress Indicator 2006, Redefining Progress, Oakland, CA.

Taylor, J.B. 2009. Getting Off Track. Stanford-Hoover Institution Press.

Tridico, P. 2012. Financial crisis and global imbalances: its labour market origins and the aftermath. Cambridge Journal of Economics 36: 17-42.

UNCTAD. 2011. Trade and Development Report 2011. Genève.

UNCTAD. 2015. UNCTAD Statistical Database, http://unctadstat.unctad.org

Urdal, H. 2008. Urban social disturbance in Africa and Asia. PRIO Papers. International Peace Research Institute, Oslo.

US Government. 2010. Economic Report of the President 2010. Washington

Vandemoortele, M. 2009. Within-Country Inequality, Global Imbalances and Financial Instability. Overseas Development Institute, London.

Varoufakis, Y. 2011. The Global Minotaur. Zed Books.

Wade, R. 2011. Income Inequality: Should We Worry About Global Trends? European Journal of Development Research 23: 513-520.

Wallernstein, I. 2001. A Left Politics for an Age of Transition, Talk at Socialist Scholars Conference. New York City, April 13, 2001.

Wolff, R. 2010. Capitalism hits the fan, Olive Branch Press, Northampton.

World Bank. 2005. World Development Report 2005: Equity and Development. Washington, DC.

World Bank. 2011. Global Development Horizons 2011.Washington, DC.

World Bank. 2012. World Bank Data, http://data.worldbank.org/ 
Figure 1.A: Real GDP Growth Rate (\%), World. 1971-2013

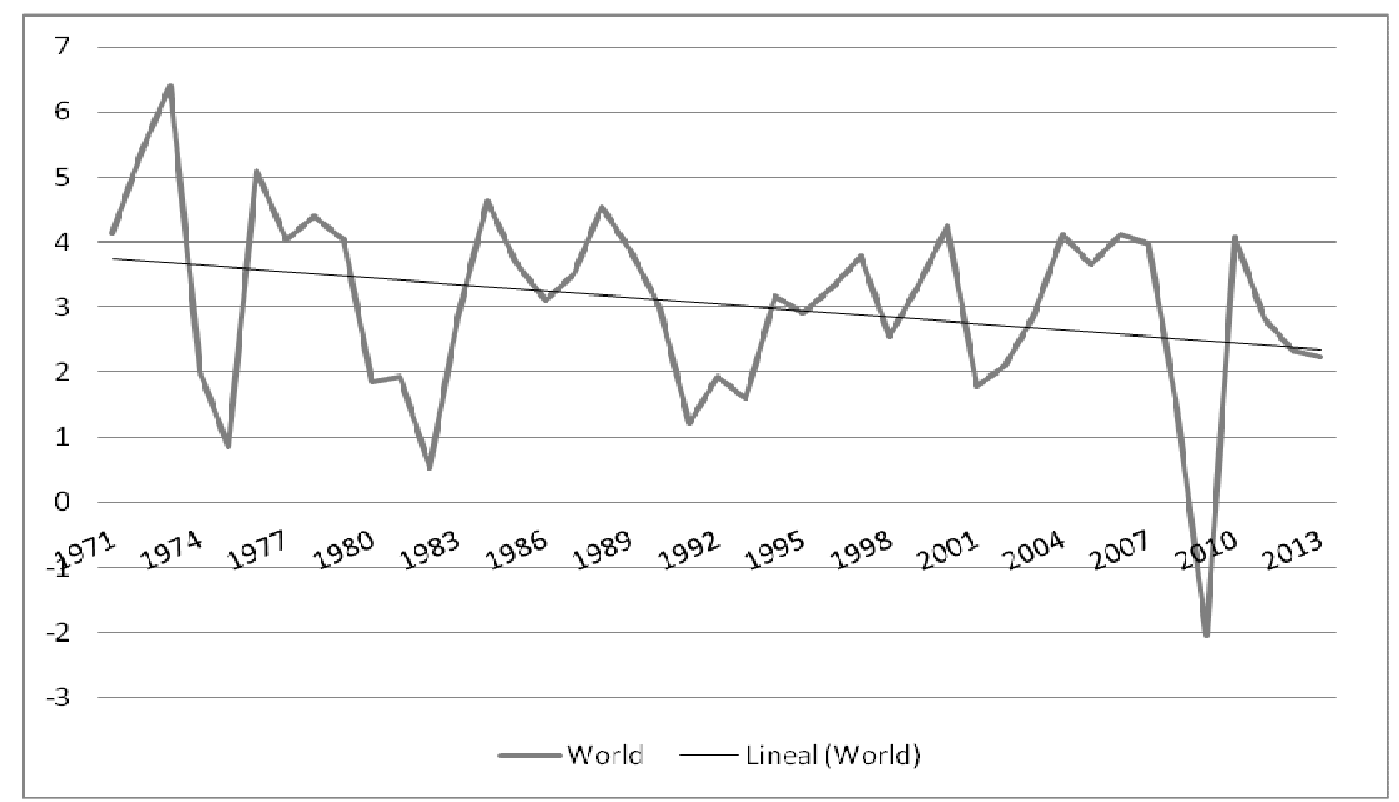

Note: Authors using UNCTAD (2015) data.

Figure 1.B: Real GDP Growth Rate (\%), Developed vs. Developing. 1970-2013

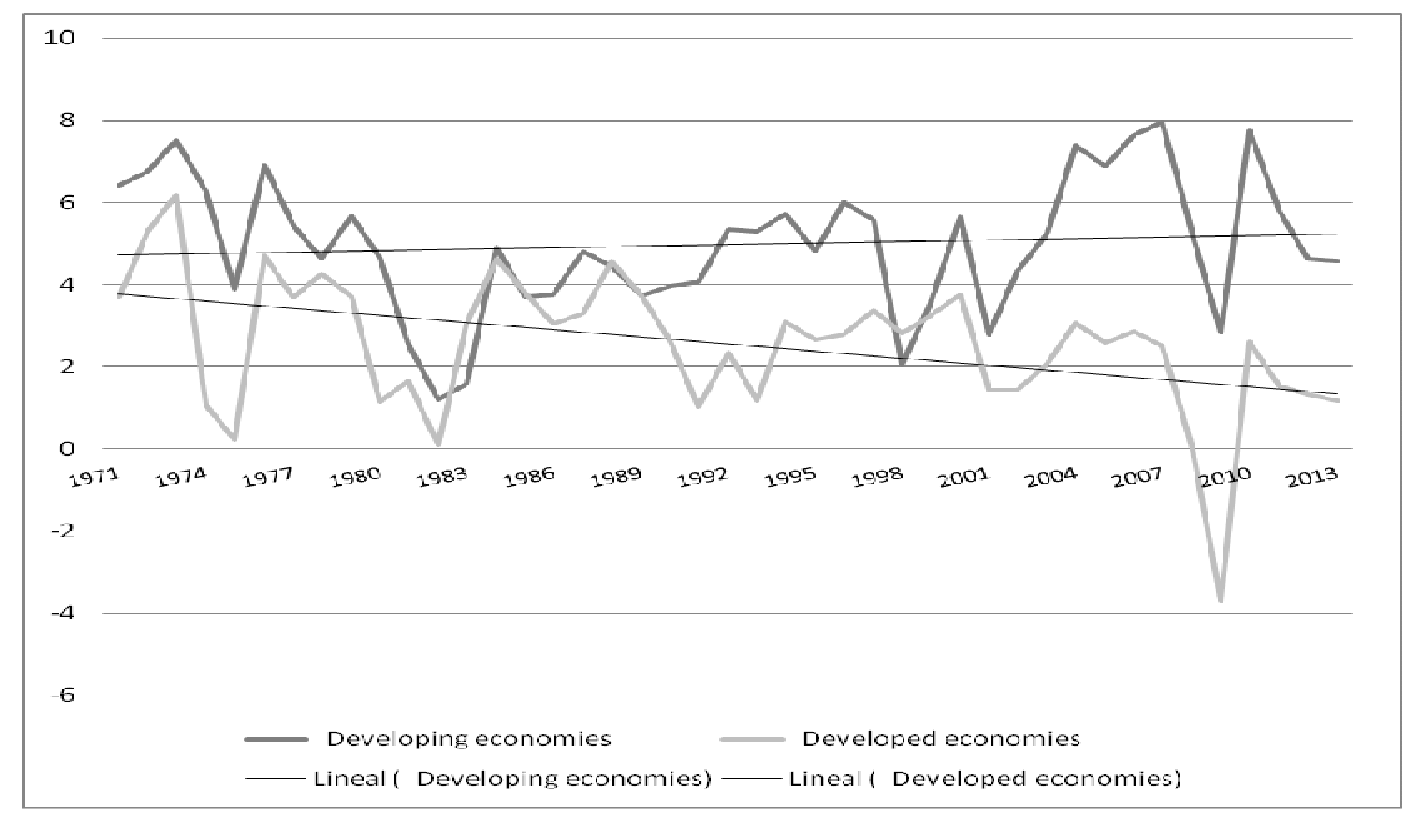

Note: Authors using UNCTAD (2015) data. 
Figure 2: Productivity and earnings

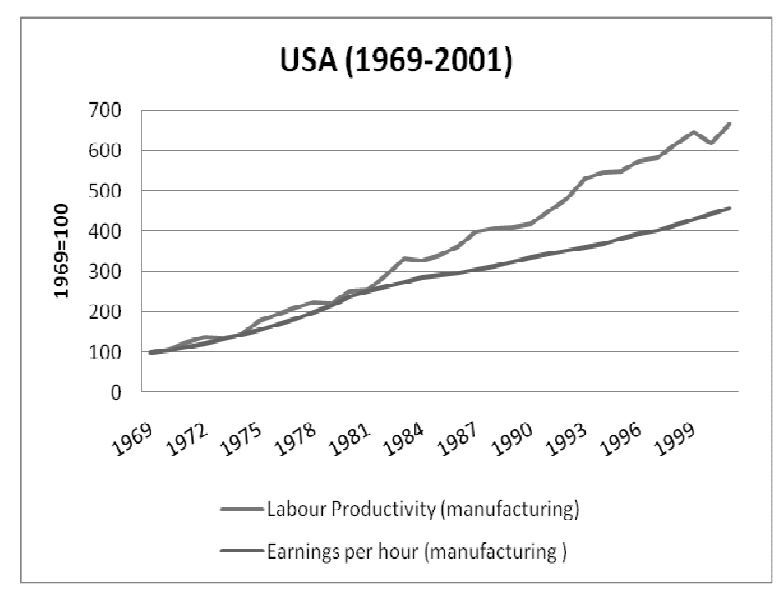

Note: Authors using ILO (2012) data.

Figure 3: Public debt. 1960-2009

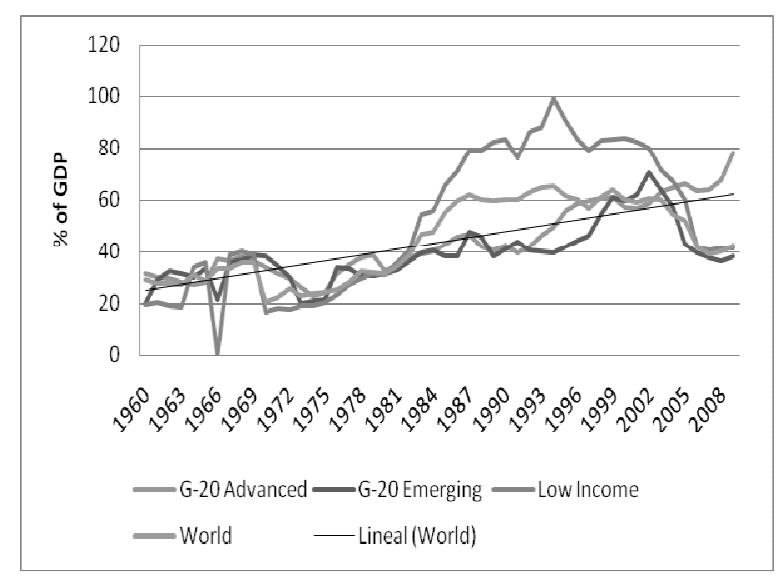

Note: Authors using IMF (2012) data

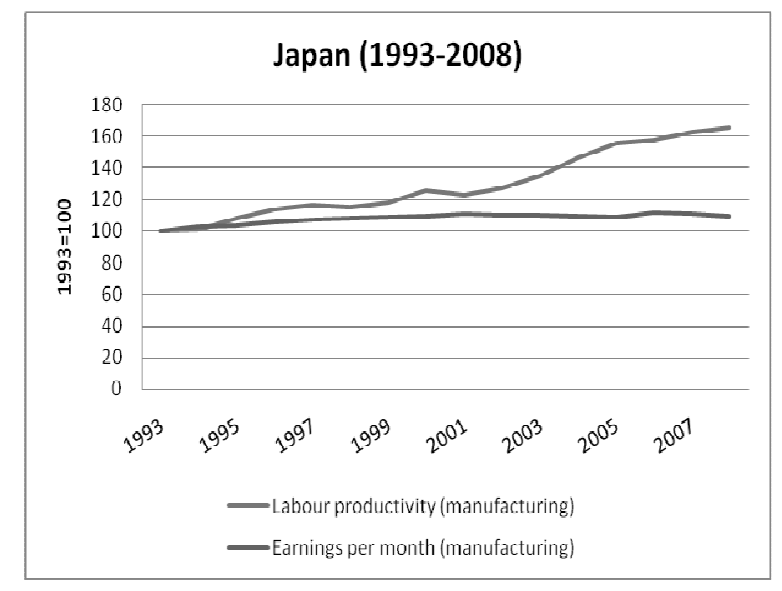

Figure 4: Household savings. 1994-2010

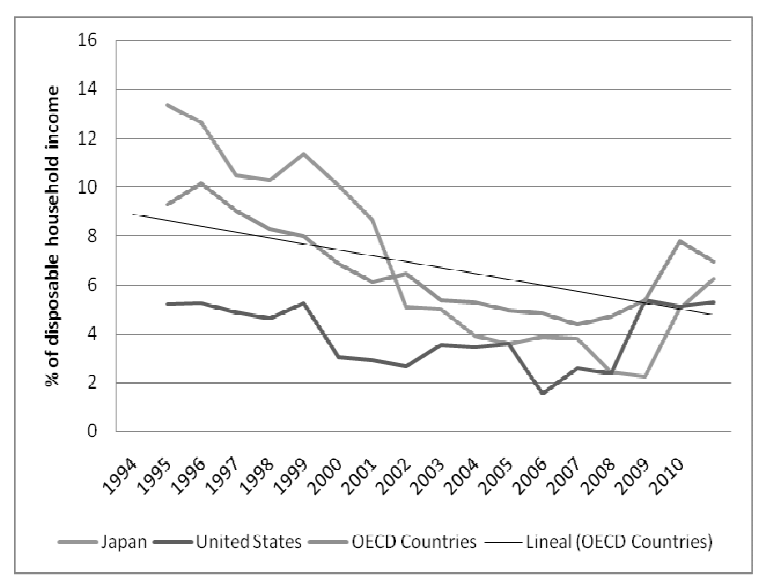

Note: Authors using OECD (2011) data 
Figure 5: Intra-country inequality. 1970-2000

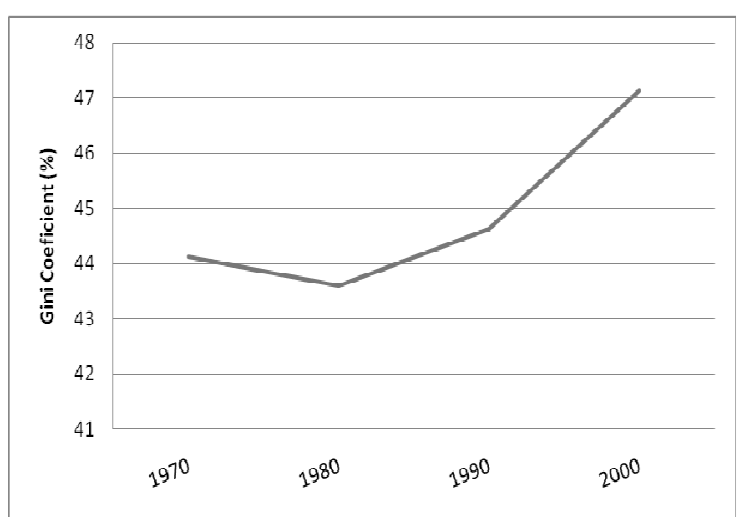

Figure 6: Global inequality. 1988-2005

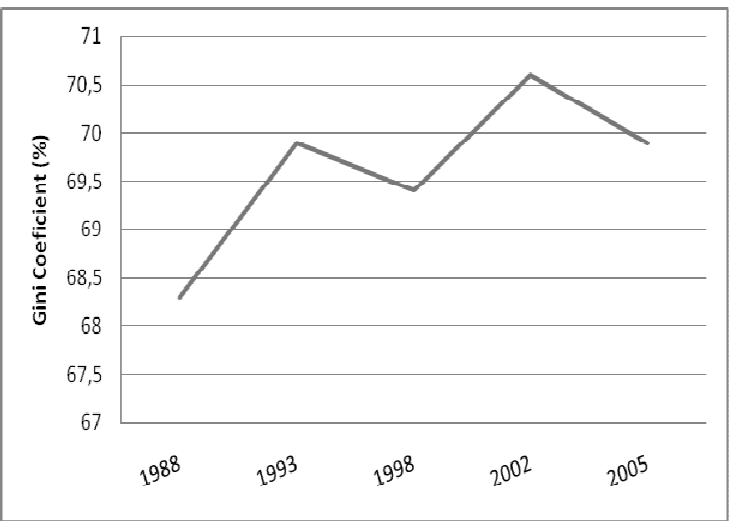

Note: Figure 5 shows average from a sample of 51 countries based on Gruen and Klasen (2008) data. Figure 6 is based on Milanovic (2012). Global inequality represents inequality among world citizens.

Figure 7: Population, Food production and Hunger

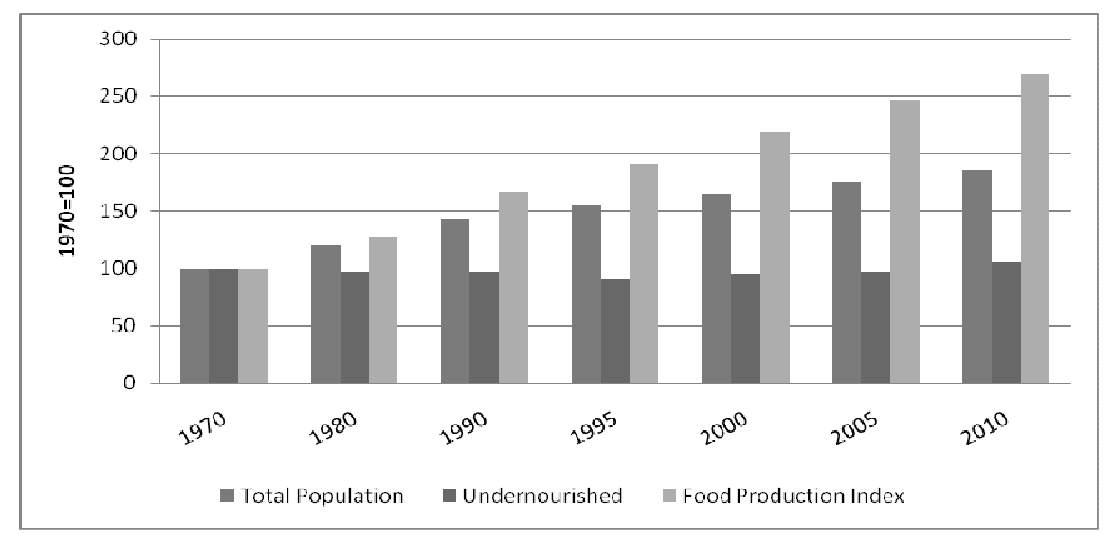

Note: Authors using WB and FAOSTAT data 
Figure 8: Humanity's Ecological Footprint and Bio-capacity. 1961-2007

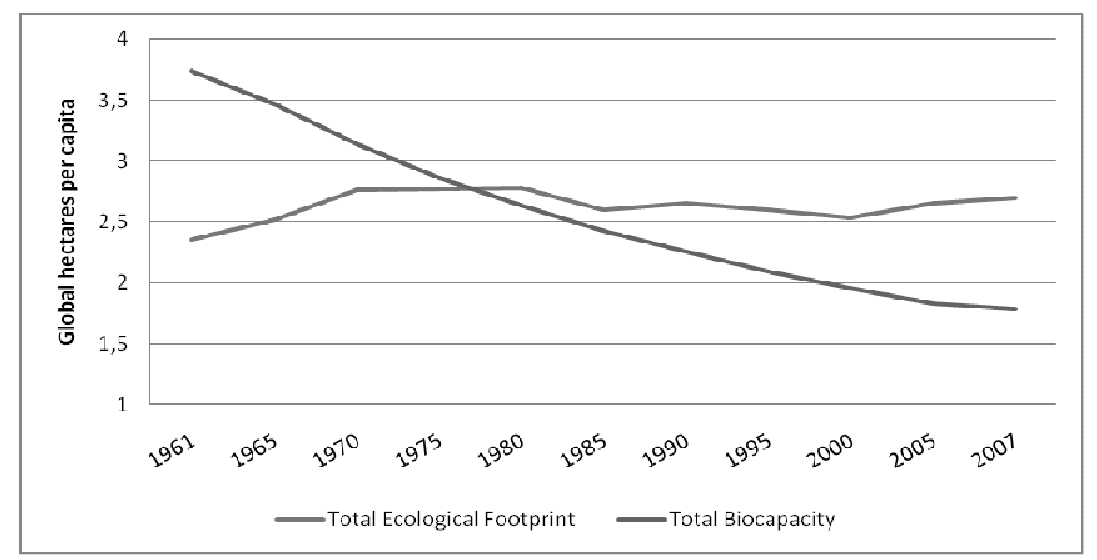

Source: Global Footprint Network (2010)

Figure 9: State-Based Armed Conflicts by Region. 1960-2007

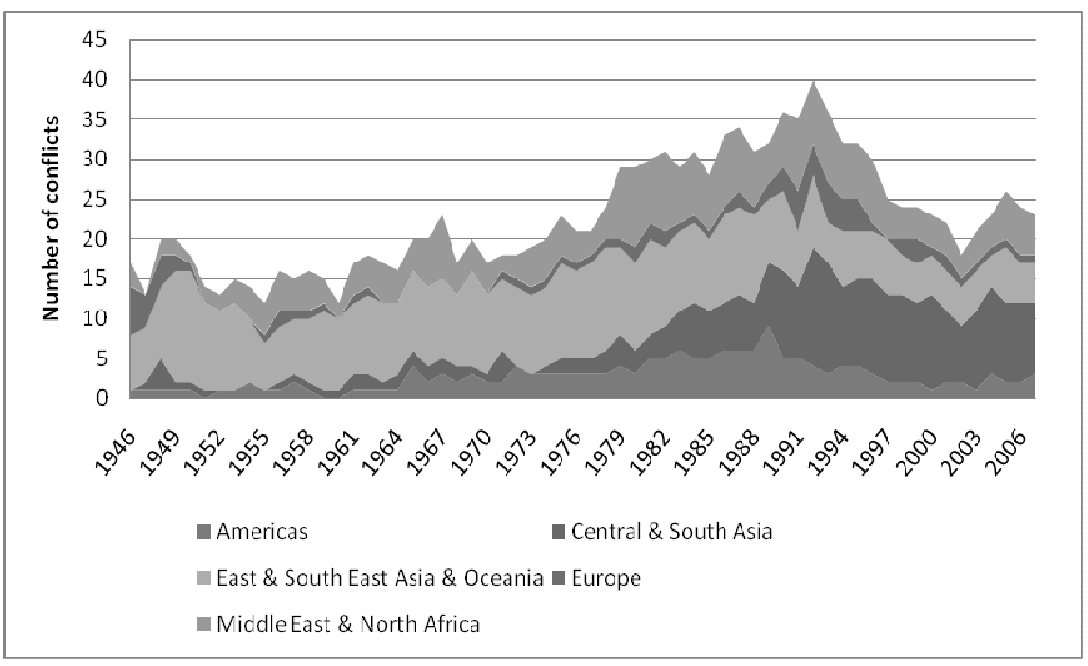

Source: Human Security Report Project (2010) 
Figure 10: Voter Turnout (selected countries), 1970-2009

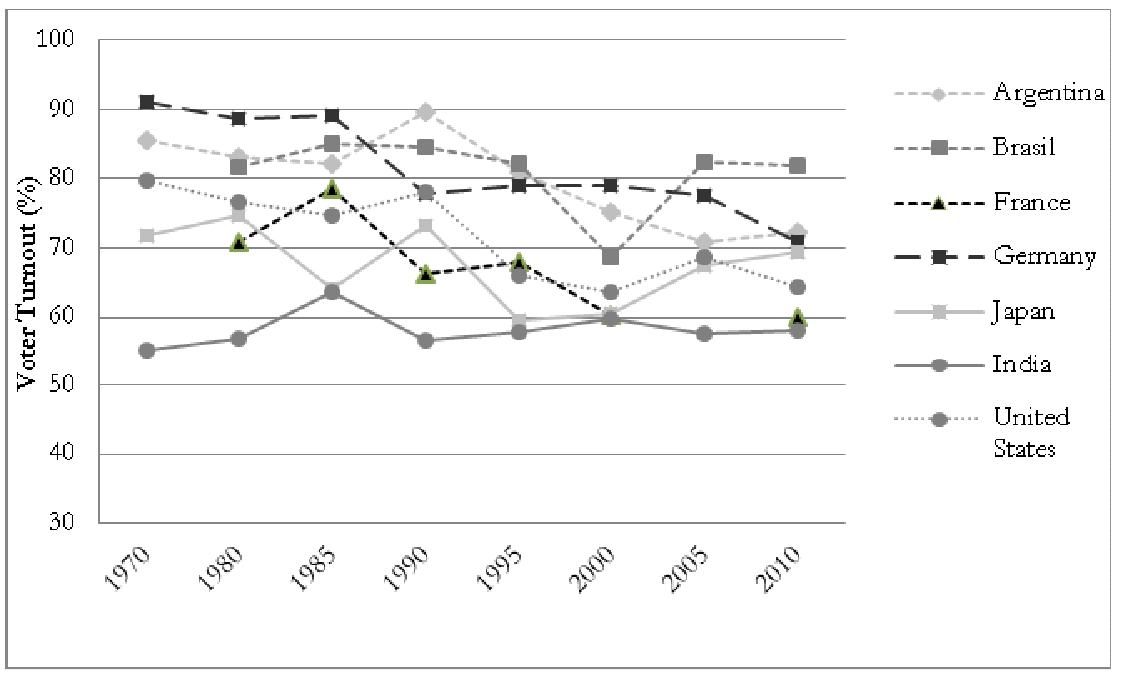

Note: Authors using International IDEA (2012) data

Figure 11: Diagram 1: Dimensions of the Systemic crisis

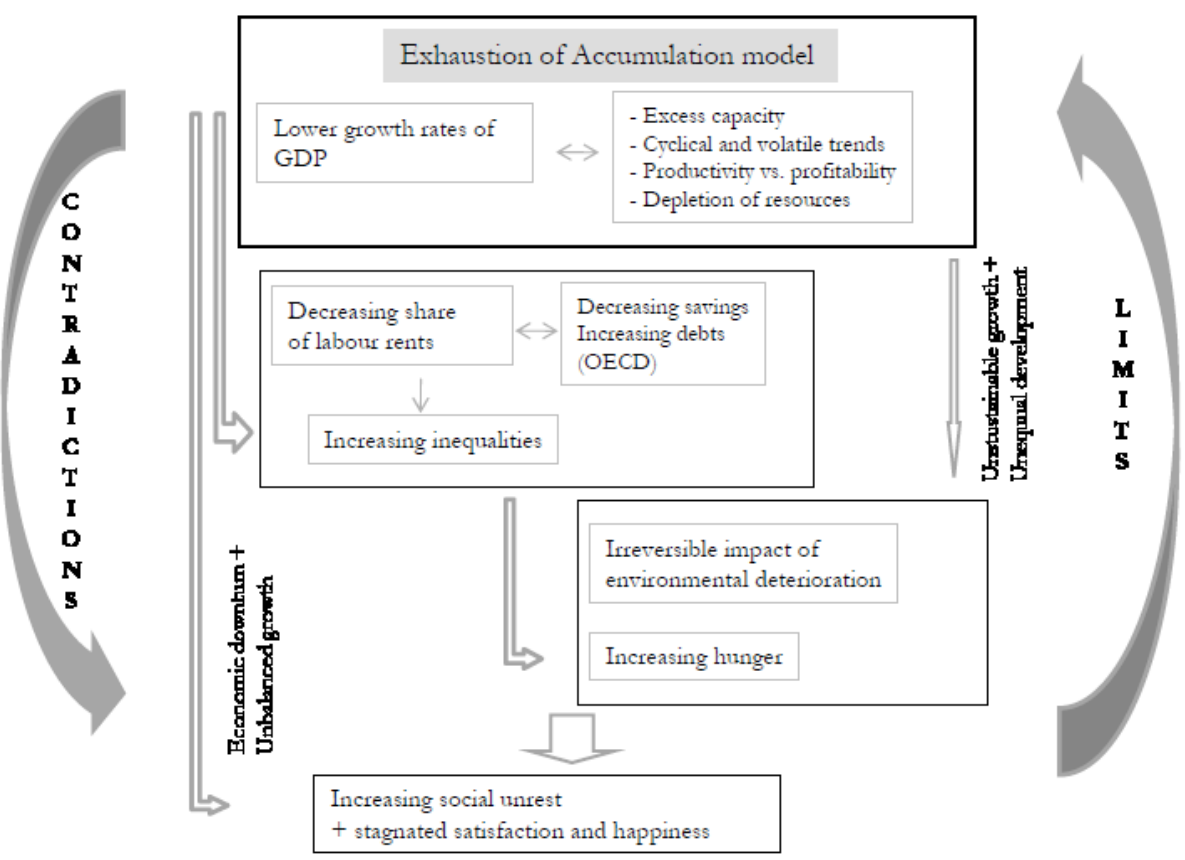


Figure 12: Per capita GDP vs. Life Satisfaction



Note: Authors using New Economic Foundation (2009) data. GDP per capita (PPP dollars. 140 countries included.

Both series have been standardized. 